\title{
Activation Pathways of Synovial T Lymphocytes Expression and Function of the UM4D4/CDw60 Antigen
}

David A. Fox, Jo Ann Millard, Li Kan, Wendy S. Zeldes, William Davis, Jay Higgs, Frank Emmrich,* and Raimund W. Kinne* Division of Rheumatology, Department of Internal Medicine, Rackham Arthritis Research Unit and Multipurpose Arthritis Center, University of Michigan Medical Center, Ann Arbor, Michigan 48109; and *Max-Planck-Society, Clinical Research Unit of Rheumatology/Immunology at the University of Erlangen-Nurnberg, Schwabachanlage 10, 8520 Erlangen, Federal Republic of Germany

\begin{abstract}
Accumulating evidence implicates a central role for synovial $T$ cells in the pathogenesis of rheumatoid arthritis, but the activation pathways that drive proliferation and effector function of these cells are not known. We have recently generated a novel monoclonal antibody against a rheumatoid synovial $\mathbf{T}$ cell line that recognizes an antigen termed UM4D4 (CDw60). This antigen is expressed on a minority of peripheral blood $T$ cells, and represents the surface component of a distinct pathway of human $T$ cell activation. The current studies were performed to examine the expression and function of UM4D4 on $T$ cells obtained from synovial fluid and synovial membranes of patients with rheumatoid arthritis and other forms of inflammatory joint disease. The UM4D4 antigen is expressed at high surface density on about three-fourths of synovial fluid $T$ cells and on a small subset of synovial fluid natural killer cells; in synovial tissue it is present on more than $90 \%$ of $\mathrm{T}$ cells in lymphoid aggregates, and on $\sim 50 \%$ of $T$ cells in stromal infiltrates. In addition, UM4D4 is expressed in synovial tissue on a previously undescribed population of HLA-DR/DP-negative non-T cells with a dendritic morphology. Anti-UM4D4 was co-mitogenic for both RA and non-RA synovial fluid mononuclear cells, and induced IL-2 receptor expression. The UM4D4/CDw60 antigen may represent a functional activation pathway for synovial compartment $T$ cells, which could play an important role in the pathogenesis of inflammatory arthritis. (J. Clin. Invest. 1990. 86:1124-1136.) Key words: rheumatoid arthritis $\bullet T$ cell activation $\bullet$ dendritic cell
\end{abstract}

\section{Introduction}

Multiple lines of evidence suggest that pathologic immune responses are of fundamental importance in rheumatoid arthritis (RA). ${ }^{1}$ These include the presence of serologic abnormalities in RA patients, infiltration of the RA synovium with lymphocytes (1), the role of lymphocytes in animal models of RA (2-7), and modulation of lymphocyte populations or function

Jay Higgs' present address is Wilford Hall USAF Medical Center, Lackland Air Force Base, San Antonio, TX 78236. The opinions expressed herein are those of the authors and do not necessarily reflect the views of the United States Air Force or the Department of Defense.

Received for publication 19 December 1988 and in revised form 17 May 1990.

1. Abbreviation used in this paper: RA, rheumatoid arthritis.

J. Clin. Invest.

(c) The American Society for Clinical Investigation, Inc.

$0021-9738 / 90 / 10 / 1124 / 13 \$ 2.00$

Volume 86, October 1990, 1124-1136 by drugs or other measures that are used in the treatment of RA (8-20), such as cyclosporine A (20).

In view of the ability of $T$ lymphocytes to respond both to antigen and to nonspecific activating signals, and to initiate and regulate immune and inflammatory responses by a range of effector cells, the $T$ cell would appear to be ideally suited to play a central role in the pathogenesis of RA. Most RA synovial lymphocytes are in fact $T$ cells $(21,22)$, and a large number of them bear surface markers indicating that they have been activated in vivo (23-25). The linkage of RA to specific class II MHC epitopes that control antigen presentation to $\mathrm{T}$ cells (26-28) implies a key role for $T$ cells and perhaps for $T$ cell responses to a particular antigen. Recent studies in animal models of RA have also emphasized the critical importance of $T$ cells, in initiating disease $(2-7,29,30)$, in mediating tissue damage (31-33), and potentially in activating immunoregulatory circuits that could prevent the development of arthritis (3, $34,35)$. A variety of methods of depleting $T$ cells from RA patients or from animals affected with diseases that are models of RA have reliably led to clinical improvement $(8,9,11$, $13-17,36,37)$, despite persistence of autoantibodies such as rheumatoid factor.

Despite these new insights, many fundamental issues remain unresolved regarding the role of T cells in RA. Although synovial $\mathrm{T}$ cells have been found to respond to microbial antigens cross-reactive with cartilage proteoglycan (38-40), the relative role of antigen-specific versus nonspecific pathways of $T$ cell activation in RA is not known. Despite evidence for a unique recognition system controlling lymphocyte adhesion to synovial vessels and subsequent migration into synovial tissue or fluid (41), the structures mediating such specific interactions are as yet uncharacterized. Although it would be desirable to specifically ablate pathogenic $T$ cells in RA without inducing a generalized $\mathrm{T}$ cell deficiency, appropriate target surface structures that are uniquely or preferentially expressed on most synovial $\mathrm{T}$ cells have not yet been described.

To address these problems, we have attempted to identify novel and functionally significant surface antigens expressed on RA synovial $\mathrm{T}$ cells, by generating monoclonal antibodies against RA synovial $T$ cell lines and clones. Using this approach, a monoclonal antibody, termed anti-UM4D4, was developed, which recognizes an antigen, termed UM4D4, that is present on about one-fourth of peripheral blood T cells (42). Although UM4D4 expression is not induced by activation of T cells, anti-UM4D4 is mitogenic for peripheral blood T lymphocytes in the presence of accessory cells or phorbol ester (42). Several types of experiments indicated that UM4D4 is distinct from the other $T$ cell surface antigens known to mediate $T$ cell activation. Although modulation of the CD3/TCR complex inhibited the mitogenic effect of anti-UM4D4, it did not affect UM4D4 expression. Binding of anti-UM4D4 was 
not blocked by a variety of other anti-T cell monoclonal antibodies. Furthermore, a variant of the malignant $T$ cell line HSB-2, selected for high expression of UM4D4, was found to express little or no CD2, CD3, and CD28. Western blotting studies using both this HSB-2 variant and RA synovial $T$ cell clones with high UM4D4 expression showed that antiUM4D4 identified a unique pattern of bands, including a 92-kD band and two smaller forms (42). The antigen recognized by anti-UM4D4 has recently been designated CDw60 $(43$, p. 361$)$.

Because UM4D4 was expressed on a higher proportion of cloned synovial $\mathrm{T}$ cells than on cloned peripheral blood $\mathrm{T}$ cells (42), it seemed likely that expression would also be greater on fresh synovial $T$ cells compared with peripheral blood $T$ cells. The present studies were therefore undertaken to determine the level of expression of UM4D4 on synovial T lymphocytes, both RA and non-RA. The data indicate that about threefourths of synovial fluid $T$ cells, as well as the majority of synovial membrane T-cells bear UM4D4, and that this novel structure represents a pathway for antigen-independent activation of these cells.

\section{Methods}

Patient populations. Synovial fluid was obtained at the time of therapeutic arthrocentesis from patients with RA and from patients with a variety of other arthritides. 32 samples were obtained from 26 RA patients (Table I), all of whom fulfilled at least four of the 1987 criteria for the classification of RA (44). 20 other synovial fluid samples were obtained from 15 patients, including four with psoriatic arthritis, four with gout, two with Reiter's syndrome, two with juvenile chronic arthritis, and one each with rheumatic fever, polymyalgia rheumatica, and pseudogout. Synovial tissue was obtained at the time of hip or knee replacement from 13 patients: 10 with RA, two with osteoarthritis and one with hemophilic arthropathy. A biopsy sample (arthroscopy) from a patient with traumatic knee injury and retropatellar chondromalacia was used as a control in immunohistology. Paired samples of peripheral blood were obtained at the time of collection of synovial fluid from six patients (four RA, one juvenile chronic arthritis, one Reiter's syndrome).

Monoclonal antibodies and isolation of mononuclear cells. The antibodies used for flow cytometric detection of cell surface markers in these studies include those previously described that identify CD2 (45), CD3 (46), CD4 (47), CD8 (47), HLA-DR (48), the natural killer cell marker CD56 (49), CD1 lb (50), CD20 (51), CD25 (52), CD26 (53), and UM4D4 (42). For dual color flow cytometry phycoerythrin-conjugated anti-CD2, CD3, CD4, CD8, CD29, CD45RA, and CD56 (Coulter Electronics, Inc., Hialeah, FL) were used in conjunction with fluorescein (FITC)-conjugated anti-UM4D4 (prepared and generously provided by Dr. Ann Jackson, Becton Dickinson Monoclonal Center, Mountain View, CA). Flow cytometry was performed using a Coulter Epics V instrument. Mononuclear cells were isolated from peripheral blood, synovial fluid and synovial tissue as described (42). Cell-free synovial fluid was obtained by centrifugation of fresh synovial fluid at $1,300 \mathrm{~g}$ for $25 \mathrm{~min}$.

Immunohistology. All samples were frozen in isopentane cooled in a bath of liquid nitrogen, and stored at $-70^{\circ} \mathrm{C}$ or in liquid nitrogen. Cryostat sections $6-8 \mu \mathrm{m}$ thick were cut at $-25^{\circ} \mathrm{C}$, air-dried, and fixed for $10 \mathrm{~min}$ in ice-cold acetone. The sections were wrapped in aluminum foil and stored at $-20^{\circ}$ until used.

Double immunofluorescence studies were performed with antibodies directed against CD2 (mAb OR $101[54$, p. 106]), CD3 (mAb UCHT1 [55]), CD4 (mAb 30F16H5 [43, pp. 314-316]), CD8 (mAb Tu 68 [54, p. 46]), the mAb UCHL1 (56), as well as antibodies directed against CD45RA (mAb 2H4 [54, pp. 242-245]), CD1 lb (mAb 44 [43, pp. 242-245]), CD11c [mAb 3.9 (43, pp. 543-551)], CD14 [mAb Clb-Mon/1 (43, pp. 787-789)], HLA-DR/DP [mAb Tu 39 (43, pp. 387-398)], and UM4D4 (42). After preincubation with heat-inactivated normal goat serum (1:5 diluted with Tris-buffered saline, TBS) for $20 \mathrm{~min}$, IgG mAbs (all except anti-UM4D4) were added for $1 \mathrm{~h}$ in dilutions between $1: 20$ and 1:200 in TBS with 1\% BSA. After washing, a fluorescein conjugated $\mathrm{F}\left(\mathrm{ab}^{\prime}\right)_{2}$ goat anti-mouse IgG antibody (Dianova, Hamburg, FRG) was applied for $30 \mathrm{~min}$ (1:40 in TBS/1\% BSA). Heat-inactivated normal mouse serum at a dilution of 1:5 (in TBS) was added for $20 \mathrm{~min}$ after repeated washes. The sections were then incubated with anti-UM4D4 diluted 1:50 in TBS/1\% BSA for $1 \mathrm{~h}$. After washing, a rhodamine conjugated $\mathrm{F}\left(\mathrm{ab}^{\prime}\right)_{2}$ goat anti-mouse IgM antibody (Dianova, Hamburg, FRG) diluted 1:50 in TBS/BSA was added for $30 \mathrm{~min}$. All incubations were done at room temperature. For controls an irrelevant IgG1 antibody (mAb MOPC21, Sigma Chemical Co., Deisenhofen, FRG) was applied instead of the first specific antibody, and a control IgM antibody (mAb TEPC 183, Sigma Chemical Co.) was used as a replacement for anti-UM4D4. No specific staining was observed in the control sections.

Alternatively the alkaline phosphatase anti-alkaline phosphatase (APAAP) technique was used. After preincubation with $20 \%$ normal goat serum for $20 \mathrm{~min}$, anti-UM4D4, diluted 1:100 with TBS containing $1 \%$ BSA, was added for $60 \mathrm{~min}$. After washing, a rabbit anti-mouse antibody (Dakopatts, Hamburg, FRG) was applied for $1 \mathrm{~h}$ (1:20 in TBS/1\% BSA). The sections were washed, incubated for $30 \mathrm{~min}$ with APAAP complex (Dianova, Hamburg, FRG; 1:100 in TBS/1\% BSA), and washed again with TBS. The alkaline phosphatase was developed in a solution prepared by dissolving $100 \mathrm{mg}$ naphthol AS-MX phos-

Table I. Clinical Characteristics of RA Patients

\begin{tabular}{|c|c|c|c|}
\hline & Synovial fluid & Synovial tissue & Total \\
\hline No. of samples & 32 & 11 & 43 \\
\hline No. of patients & 26 & 10 & 36 \\
\hline $\mathbf{M} / \mathbf{F}$ & $7 / 19$ & $2 / 8$ & $9 / 27$ \\
\hline Age* & $54 \pm 14(27-81)$ & $58 \pm 14(42-82)$ & $55 \pm 14(27-82)$ \\
\hline Duration of $\mathrm{RA}^{*}$ & $8.6 \pm 8.7(0.25-35)$ & $20 \pm 10(2-38)$ & $12 \pm 10(0.25-38)$ \\
\hline No. of ARA criteria* & $5.7 \pm 1.1(4-7)$ & $5.3 \pm 1.1(4-7)$ & $5.6 \pm 1.1(4-7)$ \\
\hline No. taking Prednisone ${ }^{\ddagger}$ & 7 & 2 & 9 \\
\hline No. on DMARD & 18 & 6 & 24 \\
\hline Positive RF & 22 & 6 & 28 \\
\hline Nodules & 8 & 3 & 11 \\
\hline
\end{tabular}

* Mean \pm SD (range). ${ }^{\ddagger}$ Mean Prednisone dose was $5 \mathrm{mg} / \mathrm{d}$ (range $1-10 \mathrm{mg} / \mathrm{d}$ ). 
phate (Sigma Chemical Co.) in $5 \mathrm{ml}$ dimethylformamide (Sigma Chemical Co.), and then adding $95 \mathrm{ml}$ of TBS (pH 8.2); $1 \mathrm{mg}$ Fast Red TR and $10 \mu$ l of $0.1 \mathrm{M}$ levamisole (both Sigma Chemical Co.) were added to $1 \mathrm{ml}$ of this solution and filtered. After washing, the sections were counterstained with Mayer's hematoxylin. Sections were viewed and photographed with a Leitz Diaplan microscope using Ektachrome 400 films for fluorescence and Afga Pan 25 films for APAAP.

Activation assays. Cultures of peripheral blood or synovial fluid mononuclear cells were set up in triplicate in 96-well U-bottom plates with 100,000 cells per well in a volume of $0.2 \mathrm{ml}$ RPMI 1640 with $10 \%$ FCS. Stimuli included anti-UM4D4 (42), a mitogenic pair of anti-CD2 antibodies (45), a mitogenic anti-CD3 antibody (57), PMA $(1 \mathrm{ng} / \mathrm{ml})$, PHA (Burroughs-Wellcome, $0.5 \mu \mathrm{g} / \mathrm{ml}$ ), recombinant IL-2 $(16 \mathrm{U} / \mathrm{ml}$ ) or combinations of the above stimuli. The antibodies were used at dilutions of ascites optimal for the detection of proliferative responses, which were measured by quantitation of $(3 \mathrm{H})-\mathrm{TdR}$ incorporation at day two, four, or six of culture.

To determine whether UM4D4 expression changed in the presence of synovial fluid, peripheral blood T cells were cultured at $10^{6}$ cells $/ \mathrm{ml}$ for $1-6 \mathrm{~d}$ in the presence of $0,1,5,10$, or $25 \%$ cell-free RA synovial fluid in RPM1 1640 with 10\% fetal calf serum. UM4D4 expression was determined by flow cytometric analysis of cell aliquots at various time points.

The expression of the p55 component of the IL-2 receptor after activation by anti-UM4D4 was measured by flow cytometry using fluoresceinated anti-IL-2R or control mouse Ig (Coulter Electronics, Inc.). For these experiments $T$ cells obtained by rosetting with sheep erythrocytes were cultured for $60 \mathrm{~h}$ in 24 -well plates at $10^{6}$ cells $/ \mathrm{ml}$ in medium alone or medium containing anti-UM4D4.

Statistical analysis of data. Groups were compared using the Student $t$ test. Groups of paired synovial fluid and peripheral blood samples were compared using the paired $t$ test. Correlation of variables was determined by linear regression analysis.

\section{Results}

Clinical characteristics of patients studied. To examine the role of the UM4D4 T cell activation pathway in synovial $\mathrm{T}$ cells, we studied synovial fluid or tissue from a total of 54 patients with RA or other forms of arthritis. Clinical characteristics of the RA patients are listed in Table I. Most of the patients were female and most had circulating rheumatoid factor. Only $25 \%$ were receiving prednisone, at doses of $1-10 \mathrm{mg} / \mathrm{d}$, but most were being treated with "disease-modifying antirheumatic drugs". The 18 patients with other forms of arthritis (diagnoses listed in Methods) included 12 men and 6 women, and the mean age $\pm S D$ of this group was $41 \pm 13$ (range, 29-64). Control synovial tissue was obtained from one additional patient with knee trauma who was otherwise healthy.

Synovial mononuclear cell surface antigens. To define the cellular composition of the synovial fluid mononuclear cells that were studied, surface markers on these cells were identified by staining with monoclonal antibodies and flow cytometric analysis. The majority of both the RA and non-RA mononuclear cells were $T$ lymphocytes, although the percentage was higher in the RA group (Table II). Sufficient cells were available from most samples to permit quantitation of $T$ cell subsets and markers indicating $T$ cell activation. The non-RA samples tended to have higher percentages of $\mathrm{CD}^{+}$cells and lower percentages of $\mathrm{CD}^{+}$cells than the RA samples (Table II). Surprisingly few cells in either group expressed the IL-2 receptor p55 protein. A higher number expressed the CD26 antigen, which is found on activated $T$ cells and on a subset of peripheral blood $\mathrm{T}$ cells that possess immunologic memory
Table II. Surface Marker Analysis of RA and Non-RA Synovial Fluid Mononuclear Cells

\begin{tabular}{lccc}
\hline & \multicolumn{2}{c}{$\%$ Positive } & \\
\cline { 2 - 3 } \multicolumn{1}{c}{ Surface antigen } & RA & Non-RA & $\begin{array}{c}P \text {, RA vs. } \\
\text { non-RA }\end{array}$ \\
\hline & $\begin{array}{c}\text { mean } \pm S D \\
(n)^{*}\end{array}$ & $\begin{array}{c}\text { mean } \pm S D \\
(n)^{*}\end{array}$ & \\
CD2 (T11) or CD3 (T3) & $68 \pm 23(32)$ & $55 \pm 29(20)$ & $P<0.05$ \\
CD4 (T4) & $30 \pm 14(22)$ & $38 \pm 20(12)$ & $0.05<P<0.10$ \\
CD8 (T8) & $22 \pm 26(22)$ & $17 \pm 11(12)$ & $P<0.05$ \\
HLA-DR & $27 \pm 30(27)$ & $21 \pm 18(17)$ & $P<0.05$ \\
CD11 1 (Mo1) & $20 \pm 22(20)$ & $31 \pm 31(17)$ & $P>0.10$ \\
CD20 (B1) & $3 \pm 4(22)$ & $3 \pm 3(16)$ & $P>0.10$ \\
CD56 (NKH1 $)$ & $11 \pm 6(8)$ & $15 \pm 5(7)$ & $P>0.10$ \\
CD25 (IL2R) & $4 \pm 4(23)$ & $5 \pm 4(13)$ & $P>0.10$ \\
CD26 (Ta $)$ & $11 \pm 11(28)$ & $16 \pm 9(15)$ & $0.05<P<0.10$ \\
& & &
\end{tabular}

* Surface markers were measured by flow cytometry. The data is expressed as the percent of cells with fluorescence above background. The number of samples analyzed for each marker is given in parentheses.

$(53,58)$. Only small numbers of B lymphocytes were found in either group. Some of the samples were also stained with an antibody to the natural killer cell antigen CD56 (NKH1a), and appreciable numbers of natural killer cells were identified in both the RA and the non-RA group. The non-RA group was more heterogeneous with respect to composition of the mononuclear cell populations than was the RA group. Samples from patients with gout contained fewer $\mathrm{T}$ cells (mean $23 \%$ ) than the remainder of the non-RA patients (mean $63 \%$ ), and the majority of the mononuclear cells in the gout samples were monocytes as judged by strong expression of CD1 $1 \mathrm{~b}$ (Mo1).

Expression of the newly-defined UM4D4/CDw60 antigen was determined. This surface structure, identified by a monoclonal antibody generated against an RA synovial $\mathrm{T}$ cell line, is expressed on a minority of peripheral blood $\mathrm{T}$ cells, resting or activated, but is expressed on a higher percentage of cells among RA synovial $T$ cell lines and clones (42). As shown in Table III, UM4D4 is present on slightly more than half of RA synovial fluid mononuclear cells. Assuming that in synovial fluid its expression is confined to $\mathrm{CD} 2^{+}$cells, of which $>95 \%$ are $\mathrm{T}$ lymphocytes and the remainder natural killer cells, it is apparent that about three-fourths of RA synovial fluid T cells, and a similar proportion of $\mathrm{T}$ cells from other synovial fluid

Table III. Expression of UM4D4

on Synovial Fluid Mononuclear Cells

\begin{tabular}{lcccc}
\hline & $\begin{array}{c}\text { No. of } \\
\text { samples }\end{array}$ & \% UM4D4 & \% T Cells* & UM4D4/T \\
\hline RA & 32 & $51 \pm 21$ & $68 \pm 23$ & $0.77 \pm 0.27$ \\
Non-RA & 20 & $40 \pm 25$ & $55 \pm 29$ & $0.73 \pm 0.25$ \\
Psoriatic arthritis & 6 & $42 \pm 28$ & $58 \pm 29$ & $0.73 \pm 0.22$ \\
Reiter's syndrome & 3 & $32 \pm 11$ & $55 \pm 17$ & $0.62 \pm 0.29$ \\
Juvenile chronic arthritis & 3 & $60 \pm 5$ & $73 \pm 16$ & $0.84 \pm 0.12$ \\
Gout & 4 & $17 \pm 29$ & $23 \pm 35$ & $0.73 \pm 0.46$ \\
Rheumatic fever & 2 & $49 \pm 2$ & $61 \pm 4$ & $0.80 \pm 0.01$ \\
Polymyalgia rheumatica & 1 & 75 & 94 & 0.80 \\
Pseudogout & 1 & 36 & 56 & 0.64 \\
& & & &
\end{tabular}

* In most cases samples were analyzed for both CD2 and CD3 expression.

When a difference was observed the higher percentage was taken as the percent $\mathrm{T}$ cells. 
samples, bear this antigen. The specificity of UM4D4 expression for $\mathrm{CD}^{+}$cells among mononuclear cells analyzed by flow cytometry is also supported by previously published data (42). Furthermore, among both RA and non-RA synovial fluid samples, the percentage of cells expressing UM4D4 correlated tightly $(P<0.001, r=0.7$ for RA group, $r=0.9$ for non-RA group) with the percent of cells expressing the cell surface markers CD2 or CD3. In both groups some samples had only small numbers of $\mathrm{CD} 2^{+}$or $\mathrm{CD}^{+}$cells and commensurately small numbers of UM4D4 ${ }^{+}$cells.

To verify the specificity of anti-UM4D4 for CD2 ${ }^{+}$cells, two-color analysis was performed on RA synovial fluid mononuclear cells stained directly with fluorochrome-conjugated monoclonal antibodies (Fig. 1). UM4D4 expression is confined to $\mathrm{CD}_{2}{ }^{+}$cells (Fig. $1 i$ ). It is clear, however, from Fig. $1 j$, that some $\mathrm{UM} 4 \mathrm{D} 4^{+}$cells are $\mathrm{CD}^{-}$. This indicated that UM4D4 was expressed on some $\mathrm{CD}^{+}{ }^{+} \mathrm{CD}^{-}$lymphocytes, a natural killer cell subset that bears some $T$ cell markers. To verify that UM4D4 is expressed on a small subset of natural killer cells, two color flow cytometric analysis was performed on mononuclear cells from peripheral blood and from RA synovial fluid that were stained with anti-UM4D4 and with an antibody to CD56, a marker present on most natural killer cells (49). The results, shown in Table IV, indicate that a small $\mathrm{UM} \mathrm{D4}^{+}$natural killer cell population can be detected in synovial fluid, and possibly in peripheral blood. It is clear, however, that most natural killer cells do not express UM4D4, and that the great majority of UM4D4 ${ }^{+}$cells do not express CD56.

It is also evident from Fig. 1 that UM4D4 can be expressed on synovial fluid $\mathrm{T}$ cells that are $\mathrm{CD}^{+}, \mathrm{CD}^{+}, \mathrm{CD} 29^{+}\left(4 \mathrm{~B} 4^{+}\right)$, or $\mathrm{CD} 5 \mathrm{RA}^{+}\left(2 \mathrm{H}^{+}\right)$. Cells negative for UM4D4 are also found in each subset. UM4D4 was expressed at a relatively high density on synovial fluid $\mathrm{T}$ cells compared with expression of other surface antigens (especially Class II MHC and IL2R), and the UM4D4 flow cytometry histogram was characteristically broad (Fig. 2).

As shown in Fig. 1, UM4D4 tended to be expressed on a greater proportion of synovial fluid $\mathrm{CD} 29^{+}$than $\mathrm{CD} 45 \mathrm{R}^{+}$ cells. However, because the majority of cells from all subsets in peripheral blood are UM4D4-negative by flow cytometric analysis (42), coexpression of UM4D4 on CD29+ cells that selectively accumulate in the synovial compartment is not likely to be the sole explanation for concentration of UM4D4 ${ }^{+}$ cells in this location. Furthermore, exposure of peripheral blood T cells to RA synovial fluid did not have a striking effect on UM4D4 expression (Table V), suggesting that high expression of this antigen on synovial fluid T cells is not likely to be due to passive adsorption of UM4D4 from synovial fluid onto the $T$ cell surface.

Data regarding UM4D4 expression on RA synovial fluid cells was analyzed further to assess whether treatment with “disease-modifying antirheumatic drugs" (DMARD'S) or prednisone affected the results. As shown in Table VI the percent UM4D4 ${ }^{+}$cells, percent total T cells, and the UM4D4/T cell ratio were not significantly different between the groups receiving or not receiving DMARD's. The percent UM4D4 ${ }^{+}$ cells was slightly higher in the group receiving low-dose prednisone than in patients not on prednisone. This appeared to reflect both a higher percent $T$ cells and a higher UM4D4/T cell ratio in the prednisone group, although neither of these parameters was significantly different from the no prednisone group when examined independently (Table VI). It is possible that the prednisone group included patients with more active disease, but available data did not permit systematic measurement of disease activity in all patients. It should be noted, however, that clinically active disease was present in all joints from which synovial fluid was obtained, because arthrocentesis was performed only when therapeutically indicated.

The data was also analyzed with respect to duration of RA. There was no correlation between duration of disease and percent UM4D4 ${ }^{+}$cells, percent total T cells, or UM4D4/total T. Equivalent UM4D4 expression was observed over disease durations ranging from 3 mo to $34 \mathrm{yr}$ (data not shown).

These results, when compared to previously published data (42), suggested that UM4D4 was expressed on a greater percentage of $T$ cells in synovial fluid than in peripheral blood. To further confirm this, six synovial fluid samples were analyzed together with paired peripheral blood collected simultaneously from the same patients. Expression of UM4D4 was somewhat higher on these peripheral blood samples ( $41 \%$ of the T cells), than on previously examined normal and RA peripheral blood lymphocytes (42). Nevertheless, UM4D4 was detected on a significantly higher proportion of cells in the paired synovial fluid samples ( $78 \%$ of the T cells, $P<0.01$ vs. paired peripheral blood samples by the paired $t$-test). The degree of expression in synovial fluid correlated with the degree of expression in peripheral blood $(r=0.92, P<0.01)$, suggesting that accumulation of UM4D4 ${ }^{+}$cells in synovial fluid is not necessarily accompanied by depletion of $\mathrm{UM}_{4} \mathrm{D}^{+}$cells from peripheral blood.

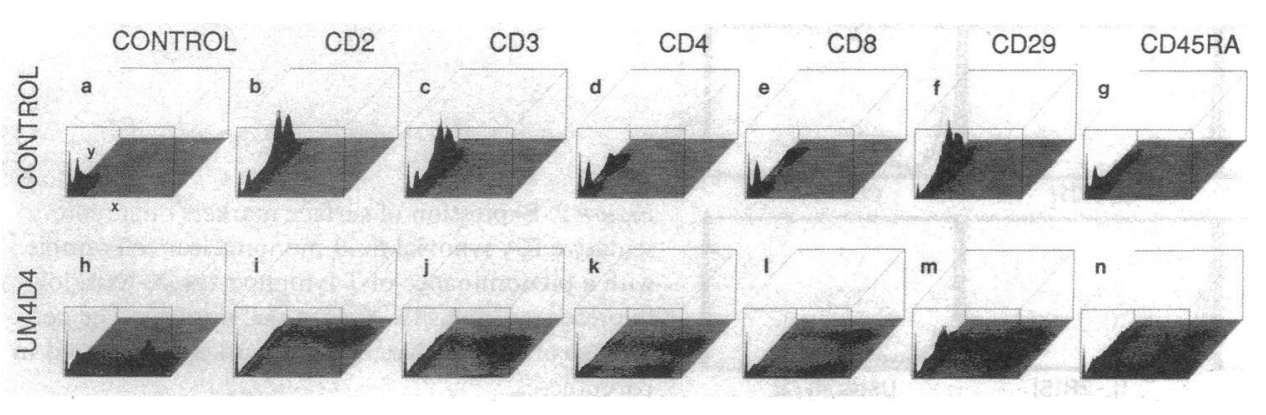

Figure 1. Expression of UM4D4 on synovial fluid mononuclear cells, analyzed by two-color flow cytometry. Cells were stained with mouse Ig-FITC $(a-g)$, or anti-UM4D4FITC $(h-n)$ and with phycoerythrinconjugated mouse $\operatorname{Ig}(a, h)$, anti$\mathrm{CD} 2(b, i)$, anti-CD3 $(c, j)$, anti$\mathrm{CD} 4(d, k)$, anti-CD8 $(e, l)$, anti-CD29 $(f, m)$ or anti-CD45RA $(g, n) . X$-Axis, log green fluorescence. $Y$-Axis, $\log$ red fluorescence. Vertical axis, cell number. Results are from a single experiment, representative of four experiments. 
Table IV. Analysis of UM4D4/CDw60 Expression on Natural Killer Cells

\begin{tabular}{lcccc}
\hline & CD2 & $\begin{array}{c}\text { CD56 } \\
\text { (NKH1a) }\end{array}$ & $\begin{array}{c}\text { CDw60 } \\
\text { (UM4D4) }\end{array}$ & $\begin{array}{c}\text { CD56/CDw60 } \\
\text { Double positive }\end{array}$ \\
\hline $\begin{array}{l}\text { A. Peripheral blood } \\
\text { mononuclear cells } \\
(n=3)\end{array}$ & $59 \pm 21$ & $14 \pm 7$ & $22 \pm 11$ & $0.3 \pm 0.6$ \\
$\begin{array}{l}\text { B. RA synovial fluid } \\
\text { mononuclear cells } \\
(n=3)\end{array}$ & $83 \pm 8$ & $14 \pm 9$ & $64 \pm 8$ & $2 \pm 1$ \\
\hline
\end{tabular}

* Results shown are the mean \pm SD of three experiments, in which surface marker expression was analyzed by dual color flow cytometry.

Analysis of UM4D4 expression on T cells digested from synovial tissue was more difficult, because several of these samples, obtained at the time of joint replacement surgery from patients with long-standing, "burned-out" disease, had very few T lymphocytes. As expected, such samples also had very few UM4D4 ${ }^{+}$cells (Fig. 3 ). The correlation between the percent $\mathrm{CD}^{+}$cells and the percent UM4D4 ${ }^{+}$cells was excellent $(P<0.001, r=0.97)$. The data suggest that the clear majority of RA synovial tissue T cells, like RA synovial fluid T cells, express UM4D4. Several osteoarthritic synovial tissue and synovial fluid specimens were examined by flow cytometry, and most yielded insufficient numbers of mononuclear cells for study. Among three non-RA synovial tissue specimens from which enough cells for could be digested (two osteoarthritis and one hemophilic arthropathy), the proportion of UM4D4 ${ }^{+}$cells in these mononuclear cell populations was $<5 \%$. This reflected a virtual absence of $\mathrm{T}$ cells from the two osteoarthritic synovial tissues, but the hemophilic arthropathy synovium contained $49 \%$ T lymphocytes among the extracted mononuclear cell population (data not shown). This specimen was unique among all of the synovial fluid and tissue specimens examined in the marked discrepancy between UM4D4 expression and the percent $T$ cells in the mononuclear cell population.

To further investigate the expression and distribution of UM4D4/CDw60 in synovial tissue, frozen sections of RA synovial biopsies that contained active inflammatory infiltrates were examined by dual color fluorescence microscopy, using antibodies against a panel of cell surface antigens. UM4D4 was present on $>90 \%$ of the $\mathrm{T}$ cells in synovial lymphoid aggregates (Fig. 4, $A$ and $B$ ). In contrast, UM4D4 was found on only $\sim 50 \%$ of the T cells in stromal infiltrates (Fig. 4, $C$ and $D$ ), as shown by double staining with an anti-CD3 antibody and
anti-UM4D4. All $\mathrm{T}$ cell subpopulations investigated $\left(\mathrm{CD} 4^{+}\right.$, $\mathrm{CD}^{+}, \mathrm{UCHL1}^{+}, \mathrm{CD} 4 \mathrm{RA}^{+}$) in different regions of the synovial membrane showed positive staining for UM4D4. In addition UM4D4" cells with a "dendritic" morphology (Fig. 4, $E$ and $F$, and Fig. 5) were found in stromal infiltrates, lymphoid aggregates, and lymphoid aggregates with germinal centers. These cells were $\mathrm{UM}_{4 D 4}{ }^{+}, \mathrm{CD3}^{-}, \mathrm{CD2}^{-}, \mathrm{CD} 14^{-}$(Fig. $4 \mathrm{E}$ ), HLA-DR/DP- (Fig. 4 F), CD1 1 ${ }^{-}, \mathrm{CD}^{-} 1 \mathrm{c}^{-}$(data not shown) in double-staining experiments. In the control sample UM4D4 was detected on $\mathrm{CD}^{+} \mathrm{T}$ cells in perivascular infiltrates. Although the $T$ cell infiltrate was much sparser in the control sample compared with RA synovia, both the proportion of $T$ cells that were UM4D4 ${ }^{+}$and the surface intensity of UM4D4 expression were similar. As in RA synovial membranes, $\mathrm{UM}_{4 D 4}{ }^{+}, \mathrm{CD}^{-}$cells with a dendritic morphology could be identified (data not shown).

Activation of synovial fluid $T$ cells in vitro. In view of the expression of UM4D4 on most synovial T cells and the ability of anti-UM4D4 to activate peripheral blood T lymphocytes, experiments were performed to determine whether this activation pathway could be triggered in synovial $T$ cells. Because information is limited regarding the response of such cells to mitogenic monoclonal antibodies that initiate $\mathrm{T}$ cell activation, the integrity of CD3-mediated and CD2-mediated responses was also examined. The mononuclear cell populations studied in these experiments included 15 RA synovial fluid samples, six non-RA synovial fluids (two rheumatic fever, two Reiter's syndrome, one juvenile chronic arthritis, one polymyalgia rheumatica), and five RA peripheral blood specimens.

The proliferative responses observed in the synovial fluid $T$ cells on day 4 were generally lower (Table VII) than in RA peripheral blood. Nevertheless, strong responses to the combination of anti-UM4D4 + PMA were seen in all three types of samples. Heterogeneity in the magnitude of this response was especially prominent in the non-RA group, in which very high responses were seen in the two rheumatic fever samples (data not shown).

A wide spectrum of responses to anti-UM4D4 + PMA was observed with RA synovial fluid lymphocytes (from $<5,000$ $\mathrm{cpm}$ to $>150,000 \mathrm{cpm}$ ). The response to anti-UM4D4 + PMA, in both the RA and non-RA synovial fluid groups, correlated with the responses to PHA, mitogenic anti-CD2 antibodies, or anti-CD3 + PMA ( $P<0.01$ in all cases). The data therefore indicate that $\mathrm{T}$ cells in an unfractionated fresh synovial mononuclear cell population can be potently activated through the UM4D4 antigen in the presence of PMA, and that the level of response seen is comparable to the maximum responses inducible by other stimuli.

Proliferative responses were also determined at day 2 and

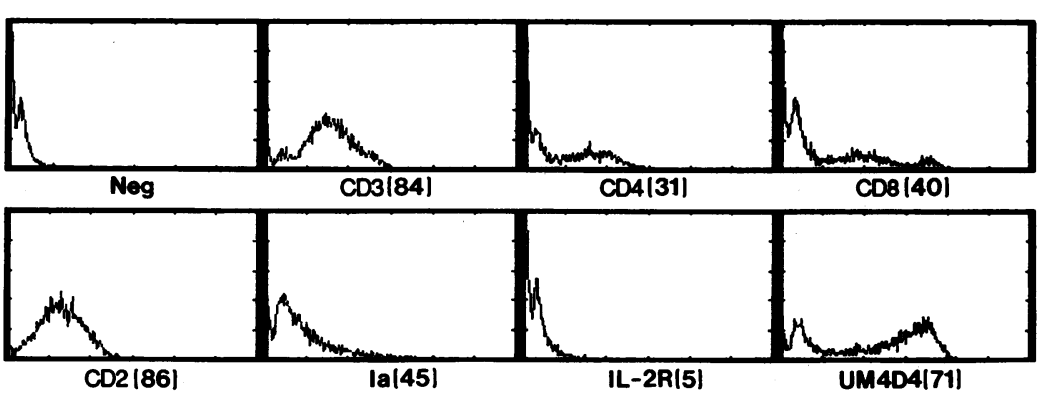

Figure 2. Expression of surface markers on a representative RA synovial fluid mononuclear cell sample with a predominance of $\mathrm{T}$ lymphocytes. $\mathrm{X}$-Axis, $\log$ fluorescence intensity. Y-Axis, cell number. The percentage of cells expressing each marker is indicated in parentheses. 
Table V. Stability of UM4D4 Expression in the Presence of Synovial Fluid

\begin{tabular}{cccc}
\hline \% Synovial fluid & Day 0 & Day 1 & Day 4 \\
\hline 0 & 26 & 25 & 28 \\
1 & 26 & 22 & 27 \\
5 & 26 & 25 & 29 \\
10 & 26 & 24 & 31 \\
25 & 26 & 23 & 29 \\
\hline
\end{tabular}

Normal peripheral blood T cells were cultured in RPMI 1640 medium with $10 \%$ FCS and the indicated concentrations of cell-free RA synovial fluid. At baseline, and after $24 \mathrm{~h}$ (day 1) and $96 \mathrm{~h}$ (day 4) UM4D4 expression was determined by flow cytometry. The results are expressed as the percent of cells positive for UM4D4.

day 6 of culture. Responses at day 2 and day 4 were comparable, but by day 6 the response to anti-UM4D4 + PMA had diminished to $30-40 \%$ of maximal levels (data not shown).

Augmentation of the mitogenic response to IL-2 by antiUM4D4 (Table VII) implied that anti-UM4D4 induced expression of IL-2 receptors. This was directly examined by culturing synovial fluid $T$ cells (isolated by fractionating RA synovial fluid mononuclear cells with sheep erythrocytes), with anti-UM4D4 for $60 \mathrm{~h}$, then measuring p55 IL-2R expression using flow cytometry. As shown in Fig. 6, anti-UM4D4 induced high-density IL-2R expression on the majority of cells. In contrast, cells cultured in medium alone (Fig. 6) expressed IL-2R at low surface density on a minority of the cells, with a histogram similar to that seen before culture (data not shown).

Previous data indicated that the response to anti-UM4D4 could be inhibited by a nonmitogenic anti-CD3 monoclonal antibody. To examine whether a mitogenic anti-CD3 anti-

Table VI. Effects of DMARD Treatment, Prednisone, and Disease Duration on UM4D4 Expression on RA Synovial Fluid Mononuclear Cells

\begin{tabular}{lccc}
\hline A. & On DMARD & Not on DMARD & $P$ \\
\hline \% UM4D4 & $57 \pm 16$ & $50 \pm 28$ & $>0.10$ \\
\% T & $70 \pm 22$ & $62 \pm 30$ & $>0.10$ \\
UM4D4/T & $0.88 \pm 0.27$ & $0.77 \pm 0.19$ & $>0.10$ \\
B. & On Prednisone & Not on Prednisone & $P$ \\
\hline \% UM4D4 & $68 \pm 11$ & $50 \pm 21$ & $<0.05$ \\
\% T & $76 \pm 17$ & $64 \pm 26$ & $>0.10$ \\
UM4D4 & $0.94 \pm 0.26$ & $0.81 \pm 0.24$ & $>0.10$ \\
\hline
\end{tabular}

Results are expressed as mean \pm SD. The data represent 26 samples from 26 different patients. 18 patients were receiving DMARD's and seven were on low-dose Prednisone. For RA patients with $>1$ synovial fluid sample available the sample with the highest percent $T$ lymphocytes was selected. In contrast, the data in Tables II and III include all samples. * DMARD's ("disease-modifying antirheumatic drugs") used included gold salts (five patients), D-penicillamine (4), azathioprine (4), anti-malarials (3), methotrexate (2), and sulfasalazine (1). One patient was receiving gold salts and an antimalarial concurrently. Several patients had undergone prior treatment with gold salts.

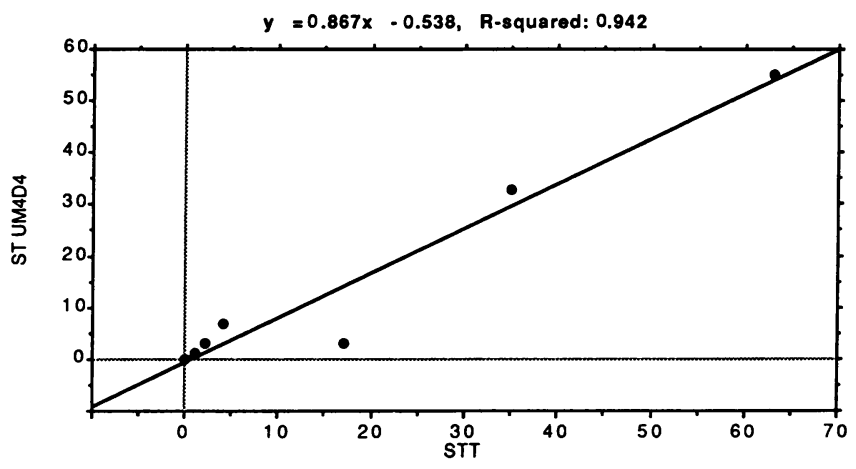

Figure 3. Correlation of UM4D4 expression with the percentage of $\mathrm{CD}^{+} \mathrm{T}$ cells in mononuclear cells isolated from RA synovial tissue. $\mathrm{X}$-Axis, percentage of $\mathrm{T}$ cells. $\mathrm{Y}$-Axis, percentage of UM4D4 ${ }^{+}$cells.

body could synergize with anti-UM4D4 in activating T cells, responses were examined using peripheral blood and synovial fluid $T$ cells that exhibited submaximal responses to either antibody alone. Anti-UM4D4 and anti-CD3 each synergized with a minimally mitogenic concentration of PMA. They did not, however, synergize with each other, either in the presence or absence of PMA. No synergy was observed over a 4-log range of concentrations of each antibody (data not shown).

\section{Discussion}

The present series of experiments was performed to investigate the level of expression and function of the recently-described UM4D4 antigen and other T lymphocyte surface antigens on synovial $\mathrm{T}$ lymphocytes. Although information is available from previous studies pertaining to the surface markers and functional responses of these cells, the current results, using a panel of monoclonal antibodies both to identify cell surface antigens and to trigger $T$ cell activation, provide a more comprehensive analysis of both RA and non-RA synovial fluid lymphocytes.

A clear majority of RA synovial fluid lymphocytes was found to be $T$ cells, consistent with previous results $(21,22)$. The non-RA synovial fluids, with the exception of gouty arthritis, also contained primarily $\mathrm{T}$ cells. The numbers of $\mathrm{CD} 4^{+}$ cells slightly exceeded the numbers of $\mathrm{CD}^{+}$cells in the RA fluids, which is in agreement with results from other laboratories $(24,59)$. The non-RA fluids tended to have a greater percentage of $\mathrm{CD}^{+}$and fewer $\mathrm{CD}^{+}$cells than the RA samples, although this observation was of borderline statistical significance. Very few B lymphocytes were present either in RA or non-RA fluids, confirming older findings in a similar spectrum of synovial fluid samples analyzed before the availability of anti-B cell monoclonal antibodies (60). Cells bearing HLADR, known to be present in the RA synovial compartment at much higher percentages than in RA peripheral blood $(24,61$, 62 ), were far more common in both our RA and non-RA samples than were cells bearing IL- 2 receptors. The relative paucity of IL-2R $\mathbf{R}^{+}$cells, noted on RA synovial tissue $\mathrm{T}$ cells (63), on RA synovial fluid T cells (62), and on synovial fluid T cells from patients with a variety of forms of juvenile chronic arthritis (64) does not necessarily imply a lack of $T$ cell activation. It may instead reflect a later stage of $T$ cell activation in 

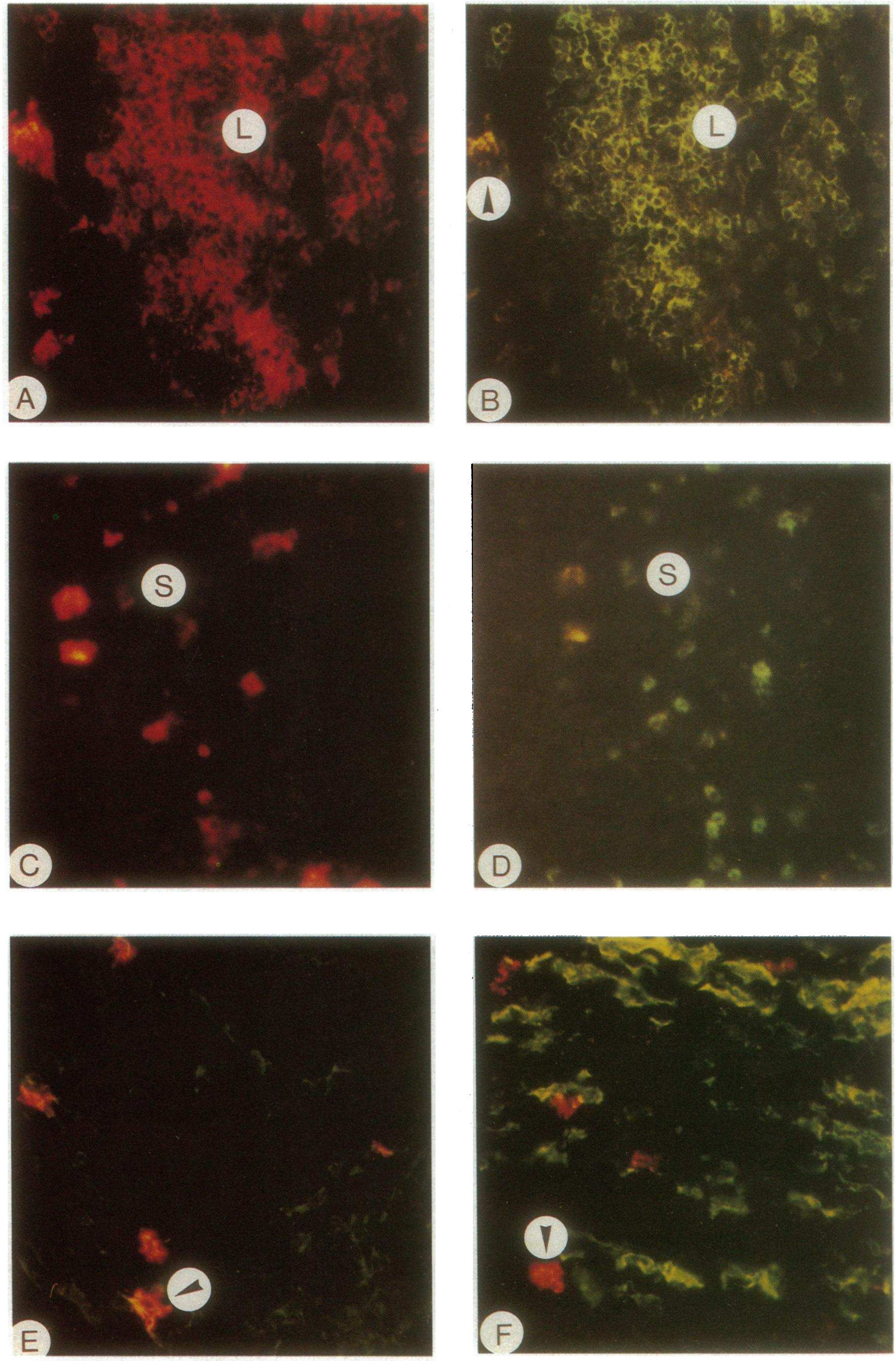


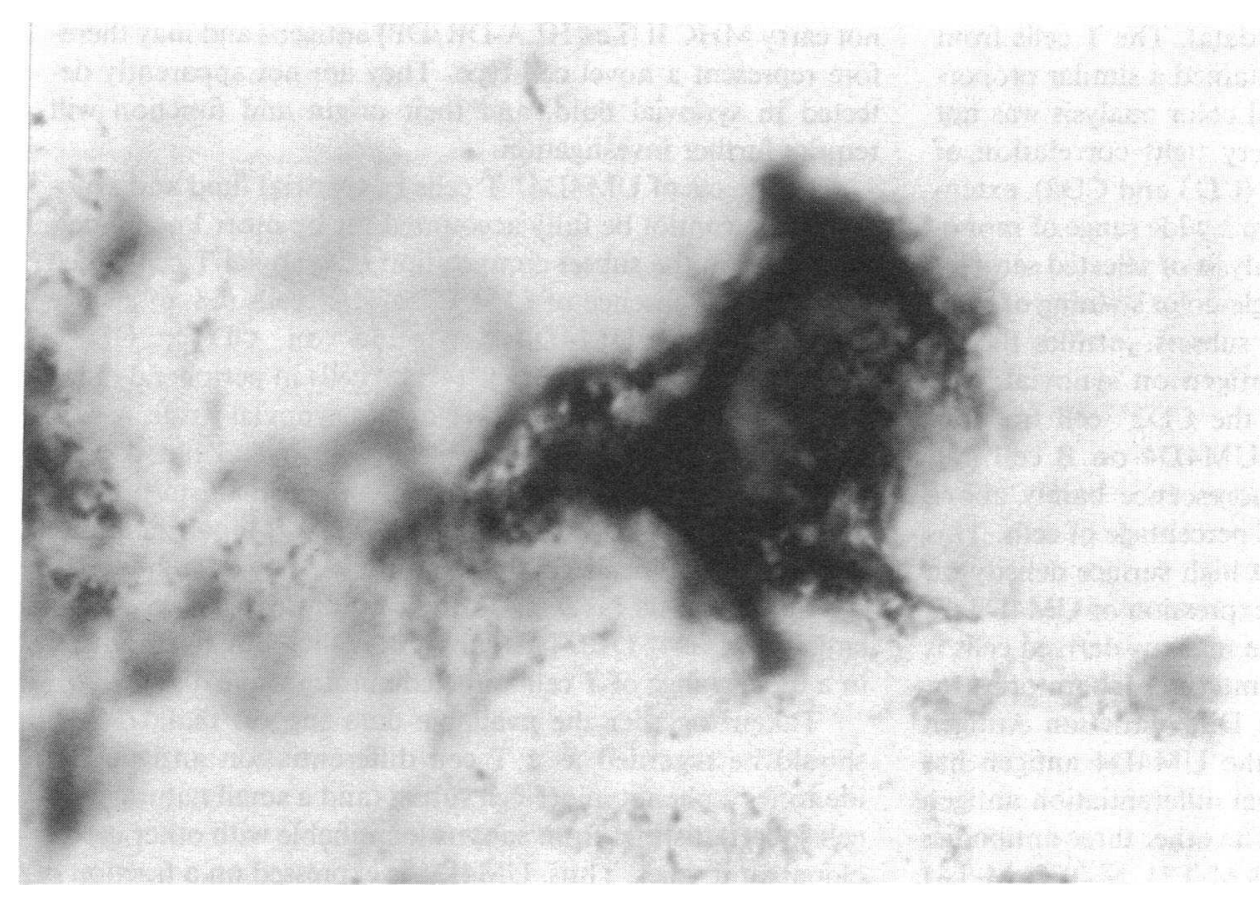

Figure 5. Immunohistological detection of UM4D4 on a cell with dendritic morphology in the stroma of RA synovial tissue by the APAAP technique. Counterstaining with hematoxylin. Magnification, 2,300 .

which IL-2 receptors, which are expressed transiently (65), have disappeared from the cell surface, and HLA-DR expression has become more prominent. This hypothesis is consistent with observations that expression of IL-2R and HLA-DR on individual $T$ cells tends to be mutually exclusive (66). Expression of another marker of $\mathrm{T}$ cell activation, CD26 (Tal), was not significantly different on synovial fluid lympho- cytes than was previously noted on normal peripheral blood $\mathrm{T}$ cells (53).

The most striking new finding regarding the surface phenotype of synovial $T$ cells was the intense expression of the antigen termed UM4D4 (recently designated CDw60) on approximately three-fourths of the cells. In contrast it is expressed on a minority of peripheral blood T cells from normal subjects (42)

Table VII. Mononuclear Cell Proliferative Responses

\begin{tabular}{lccc}
\hline & \multicolumn{3}{c}{ Mononuclear cell populations } \\
\cline { 2 - 4 } \multicolumn{1}{c}{ Stimuli } & RA PB (5) & RA SF (15) & Non-RA SF (6) \\
\hline PHA & $48248 \pm 6077$ & $24158 \pm 4368$ & $28114 \pm 10148$ \\
Anti-T11 2 + Anti-T11 & $51045 \pm 7998$ & $25834 \pm 5755$ & $9626 \pm 4270$ \\
PMA & $10276 \pm 664$ & $2900 \pm 1928$ & $292 \pm 207$ \\
Anti-CD3 & $9005 \pm 5728$ & $3183 \pm 1791$ & $3566 \pm 2305$ \\
Anti-CD3 + PMA & $104276 \pm 25348$ & $56353 \pm 11836$ & $66559 \pm 29643$ \\
Anti-UM4D4 & $558 \pm 287$ & $3293 \pm 1374$ & $1900 \pm 1268$ \\
Anti-UM4D4 + PMA & $104043 \pm 17654$ & $46737 \pm 10333$ & $59168 \pm 33114$ \\
IL-2 & ND & $7247 \pm 1921$ & $8364 \pm 3656$ \\
Anti-UM4D4 + IL-2 & ND & $25335 \pm 8271$ & $61689 \pm 29362$
\end{tabular}

Results are expressed as the mean of the means of triplicate cpm \pm SEM, representing thymidine incorporation at day 4 of culture. The cpm obtained from unstimulated control cultures have been subtracted. The number of patients studied in each group is indicated in parentheses. The RA PB samples were paired with five of the 15 RA SF samples. Results of the paired and unpaired RA SF samples were not significantly different.
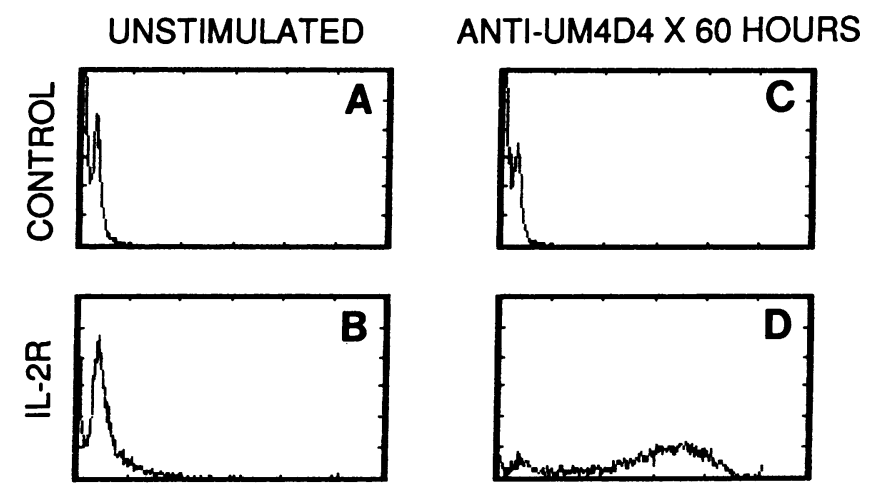

Figure 6. Induction of IL-2 receptors on synovial fluid T cells by anti-UM4D4. Cells were cultured as described in Methods in medium alone $(A, B)$ or with anti-UM4D4 $(C, D)$, then stained with mouse Ig-FITC $(A, C)$ or anti-IL-2R-FITC $(B, D)$. $X$-Axis, log green fluorescence. $Y$-Axis, cell number.

Figure 4. Rheumatoid arthritis synovial tissue. Magnification for all pictures, 350. (A-D) Double immunofluorescence with anti-CD3 (fluorescein) and anti-UM4D4 (rhodamine). The yellow spots at the left margins of panels $B$ (arrowhead) and $D$ are artifacts due to an overspill of bright red fluorescence. $(A)$ Single exposure for the detection of UM4D4 (red). $L$, lymphoid aggregate. (B) Single exposure for the detection of CD3 (green). $L$, lymphoid aggregate. ( $C$ ) Single exposure for the detection of UM4D4 (red). $S$, stromal infiltrates. (D) Single exposure for the detection of CD3 (green). $S$, stromal infiltrates. $(E)$ Double immunofluorescence with anti-CD14 (fluorescein) and anti-UM4D4 (rhodamine). Double exposure for CD14 (green) and UM4D4 (red). Stromal infiltrate. Arrowhead, cell with dendritic morphology. $(F)$ Double immunofluorescence with anti-HLA-DR/DP (fluorescein) and anti-UM4D4 (rhodamine). Double exposure for HLA-DR/DP (green) and UM4D4 (red). Stromal infiltrate. Arrowhead, cell with dendritic morphology. 
or patients with RA (42 and current data). The T cells from non-RA synovial fluid specimens contained a similar proportion of UM4D4 ${ }^{+}$cells. Although dual color analysis was not performed on most samples, the very tight correlation of UM4D4 and the pan-T cell antigens (CD3 and CD2), extensive prior screening of anti-UM4D4 on a wide range of mononuclear cell populations (42), and analysis of selected samples using two-color flow cytometry or single-color staining of purified synovial fluid mononuclear cell subsets, justifies the assumption that expression of this antigen on synovial fluid mononuclear cells was confined to the $\mathrm{CD} 2^{+}$cell fraction. Previously reported expression of UM4D4 on B cell and monocyte lines (42) represented fluorescence barely above background and generally on a small percentage of cells. This contrasts to expression of UM4D4 at high surface density on most UM4D4 ${ }^{+} \mathrm{T}$ cells. The specific expression of UM4D4 on a $\mathrm{T}$ cell subset among nucleated bone marrow derived cells is supported by studies performed in multiple laboratories for the Fourth International Leukocyte Differentiation Antigen Workshop. Based on these results the UM4D4 antigen has been provisionally assigned to a novel differentiation antigen cluster termed CDw60 (43, p. 361). The other three antibodies assigned to the CDw60 cluster (mAbs M-T21, M-T32, M-T41 $[43$, p. 361$]$ ) showed a staining pattern very similar to antiUM4D4 on RA synovial membranes (data not shown).

The data also demonstrate expression of UM4D4 on a small number of $\mathrm{CD}^{+} 6^{+}$natural killer cells. This is also reflected in the presence of a very small $\mathrm{CD} 2^{+} \mathrm{UM} 4 \mathrm{D} 4^{+} \mathrm{CD}^{-}$ subset in synovial fluid. However, the great majority of $\mathrm{UM} \mathrm{D}^{+}$cells in the synovial fluid are conventional $\mathrm{CD}^{+} \mathrm{CD}^{+} \mathrm{T}$ lymphocytes. No UM4D4 ${ }^{+} \mathrm{CD} 2^{-}$cells were found in synovial fluid.

The reason for the dominance of UM4D4 ${ }^{+} \mathrm{T}$ cells in the synovial compartment is not yet known, and several mechanisms are possible. Cells expressing UM4D4 could have a special tendency to migrate into synovial tissues, perhaps by virtue of an adhesive interaction involving the UM4D4 receptor itself or by induction of synovial homing receptors after activation of cells through UM4D4 in peripheral compartments. Alternatively, the UM4D4 ${ }^{+}$subset could expand preferentially once within the synovial compartment, if the mitogenic ligand(s) capable of binding to UM4D4 was locally available. Finally, it is possible that UM4D4- cells might differentiate into UM4D4 ${ }^{+}$cells in situ. This latter alternative seems unlikely, because even long-term $\mathrm{T}$ cell activation does not appear to increase UM4D4 expression, as long as the activating stimulus is not directed at the UM4D4 antigen (42). The current data do not, however, formally exclude this possibility.

Clear cut differential expression of UM4D4 on T cells in different regions of the synovial membrane was observed in these studies. This differential expression could either be due to a preferential entry of UM4D4- vs. UM4D4 ${ }^{+}$cells into different regions of the synovial membrane or, less likely, due to changes in expression of UM4D4 on synovial T cells during migration from one area of synovial tissue to another.

The UM4D4 antigen was also detected on cells with a dendritic morphology in RA (Fig. 4, $E$ and $F$, Fig. 5) and normal synovial membranes. Because these cells were $\mathrm{CD}^{-}$ and $\mathrm{CD} 2^{-}$, they are not $\mathrm{T}$ cells. They did not show a positive reaction for CD14, CD1 lb, and CD1 1c and most likely do not belong to the monocyte/macrophage cell type. In contrast to the classic dendritic cell of the synovial membrane (67) they do not carry MHC II (i.e., HLA-DR/DP) antigens and may therefore represent a novel cell type. They are not apparently detected in synovial fluid, and their origin and function will require further investigation.

The excess of UM4D4 ${ }^{+} \mathrm{T}$ cells in synovial fluid and synovial tissue cannot be fully accounted for by other known perturbations in the subset composition of synovial $\mathrm{T}$ cells, such as the virtual absence of $\mathrm{CD}^{+} \mathrm{CD} 45 \mathrm{RA}^{+}$cells $(68,69)$, since expression of UM4D4 is found on $\mathrm{CD}^{+}, \mathrm{CD}^{+}$, $\mathrm{CD} 45 \mathrm{RA}^{+}\left(2 \mathrm{H}^{+}\right)$, and $\mathrm{CD} 29^{+}\left(4 \mathrm{~B} 4^{+}\right)$cells in peripheral blood (42), in synovial fluid (Fig. $2 A$ ), and in synovial tissue, as well as on the $\mathrm{CD4}^{+} \mathrm{CD} 45 \mathrm{RA}^{+}$subset in peripheral blood (Fox, D. A., unpublished data). Whatever the mechanism of accumulation of UM4D4 ${ }^{+}$cells in the synovial compartment, it is clear that other localized $T$ cell infiltrates, such as cutaneous $T$ cells in psoriasis (as well as their clonal progeny) also are largely UM4D4 ${ }^{+}(70)$. This subset may therefore be important in a broad range of $\mathrm{T}$ cell-directed autoimmune diseases.

Taken together the available data suggest that UM4D4 should be regarded as a $\mathrm{T}$ cell differentiation antigen that identifies a phenotypic $T$ cell subset (and a small natural killer cell subset) distinct from subsets identifiable with other monoclonal antibodies. Thus, UM4D4 is expressed on a fraction of each of at least five mature $\mathrm{CD} 2^{+}$populations: $\mathrm{CD} 3^{+} \mathrm{CD} 4^{+}$, $\mathrm{CD}^{+} \mathrm{CD}^{+}, \mathrm{CD}^{+} \mathrm{CD}^{2} 9^{+}, \mathrm{CD}^{+}{ }^{+} \mathrm{CD} 45 \mathrm{RA}^{+}$, and $\mathrm{CD}^{+} \mathrm{CD}^{-}$ cells. It is also expressed on $\sim 6 \%$ of thymocytes, including cells within various thymocyte subsets (71). In view of expression of UM4D4 on all these populations it appears likely that the functional repertoire of $\mathrm{UM}^{2} \mathrm{D4}^{+}$cells will be heterogeneous. Study of the functional abilities of freshly isolated UM4D4 ${ }^{+}$cells would be greatly facilitated by development of a monoclonal antibody that could recognize the reciprocal (UM4D4 ${ }^{-}$) population, and therefore allow isolation of the UM4D4 ${ }^{+}$subset without the use of an antibody that itself affected the function of these cells (i.e., anti-UM4D4). Preliminary experiments indicate that both UM4D4 ${ }^{+}$and UM4D4 ${ }^{-}$ peripheral blood $\mathrm{T}$ cells can proliferate in response to PHA, anti-CD2, anti-CD3, or IL-2 (data not shown).

Because previous studies indicated that UM4D4 represented a novel pathway of human $T$ cell activation (42), experiments were performed to assess the integrity of this and other $\mathrm{T}$ cell activation pathways in synovial fluid T cells. Activation of human $T$ cells can be initiated by ligands of the CD3/TCR (antigen-MHC receptor) (57), by ligands of CD2, the sheep erythrocyte receptor (45), or by mitogenic lectins such as PHA. Most T cell activation signals, such as soluble anti-CD3 antibodies (72), require intact accessory cell function. The addition of minimally mitogenic amounts of the phorbol ester PMA bypasses this accessory cell requirement, and permits direct assessment of $T$ cell proliferative capacity (73). Similarly, certain ligands of CD2 appear to function in a manner independent of accessory cells (45). The response to UM4D4 among fresh peripheral blood $T$ cells is dependent upon accessory cell help, but similar to anti-CD3, this can be replaced by low concentrations of PMA (42). In the present studies, therefore, the use of anti-CD3 + PMA, a combination of two anti-CD2 antibodies (anti-T1 $11_{2}$ and anti-T1 $1_{3}$ ), and anti-UM4D4 + PMA, allowed direct determination of the full potential of synovial $T$ cells to be activated through these pathways.

Previous studies of patients with RA have suggested subtle defects in the activation responses of peripheral blood $\mathrm{T}$ cells, 
and more severe abnormalities in the function of synovial $\mathrm{T}$ lymphocytes $(61,74-89)$. Among RA peripheral blood lymphocytes, decreased responses to lectins have been observed in most $(74-76,78,80,82)$ but not all $(88)$ studies. Decreased peripheral blood $\mathrm{T}$ cell responses to antigen occur in vivo and in vitro in a subgroup of patients $(77,85,86)$, and may indicate more severe disease activity $(85,86)$. RA synovial $T$ cells have markedly diminished responses to lectins $(75,79,83)$, to autologous non-T cells (83) and to soluble anti-CD3 (87). These defective responses have been attributed to inhibitors of IL-1 action $(87)$, or of IL-2 production and function $(90,91)$. Despite these findings, elevated levels of soluble IL-2R have been found in RA synovial fluid (92), which, along with surface expression of class II MHC molecules $(23,24)$ suggests that T cell activation has occurred. The defective $\mathrm{T}$ cell responses seen in vitro may therefore reflect activation of regulatory circuits designed to down-modulate further $T$ lymphocyte stimulation.

Consistent with these previous findings the response to PHA in the present study was lower in RA synovial fluid T cells than in RA peripheral blood (Table VII, $P<0.025$ ). The equivalent depression of the response to anti-CD2 (Table VII, $P<0.01$ ), demonstrates that inadequate accessory cell function cannot fully explain all of the defective $\mathrm{T}$ cell responses, because the particular anti-CD2 stimuli used function in the absence of accessory cell help (45). However, the 18-fold augmentation of synovial fluid $T$ cell responses to anti-CD3 by small amounts of PMA indirectly suggests that inadequate accessory cell function is also present. Similarly anti-UM4D4 alone induced only modest proliferative responses, which were lower than those previously observed (42) in normal peripheral blood $\mathrm{T}$ cells. In the presence of PMA, however, antiUM4D4 induced brisk mitogenic responses, comparable to the maximal responses obtained with any of the other stimuli (Table VII). The role of PMA in greatly increasing responses to anti-UM4D4 may reflect the presence of inadequate accessory cell signals, for which PMA can substitute. Alternatively or additionally, PMA may be overcoming inhibitory factors generated in the mononuclear cell cultures. Synergistic effects were also seen with the combination of anti-UM4D4 and IL-2 (Table VII), suggesting that anti-UM4D4 increased IL-2 receptor expression on these cells, and this was verified directly (Fig. 6). For all responses the results with the non-RA synovial fluid $T$ cells were comparable with those with the RA synovial fluid $T$ cell samples, with no statistically significant differences observed.

The results therefore indicate that multiple activation pathways can function in synovial fluid $\mathrm{T}$ cells, although responses may be depressed in magnitude at the time of testing in vitro. In both respects RA synovial fluid $T$ cells do not appear to be different from $T$ cells from synovial fluid of other inflammatory arthritides.

It is not known at present whether the pathways that operate in vitro in the absence of antigen can be similarly triggered in vivo. With respect to the $\mathrm{CD} 2$ pathway, immature thymocytes, that lack antigen receptors, can be activated either by antibodies to CD2 (52), or by LFA-3, the natural ligand of CD2 (93). In the case of UM4D4, in vivo functioning of this pathway would require the presence of mitogenic endogenous ligands capable of binding to the UM4D4 molecule. The nature of such ligands, and whether they are cell surface molecules or soluble factors, is unknown at present. In individual synovial fluid $\mathrm{T}$ cell samples the magnitude of the response to anti-UM4D4 + PMA correlated strongly with the magnitude of other $T$ cell responses, suggesting that regulatory mechanisms affecting the $C D 3$ and $C D 2$ pathways similarly affect the UM4D4 pathway. This is consistent with previous evidence demonstrating that $\mathrm{T}$ cell activation pathways are functionally interrelated $(94,95)$, and with the observation that UM4D4, like other forms of $\mathrm{T}$ cell activation, can be regulated by modulation of the CD3/TCR complex (42).

If the intense expression of UM4D4 on RA synovial T cells is indeed parallelled by a special role for this activation pathway in the synovial compartment, the UM4D4 pathway could contribute to chronic local polyclonal $\mathrm{T}$ cell activation that would persist in the absence of specific antigen. Therapeutic strategies, designed to ablate or functionally paralyze the UM4D4 ${ }^{+}$cells, might therefore offer a new approach to suppression of a compartmentalized autoimmune response, that would have no deleterious effect on the majority of peripheral blood $\mathrm{T}$ cells needed for normal host defenses.

\section{Acknowledgments}

We thank Drs. Ellis Reinherz, Stuart Schlossman, Lee Nadler, Robert Todd, James Griffin, Jerome Ritz, and P. L. C. Beverly for generous gifts of monoclonal antibodies. We are grateful to the Cetus Corporation for recombinant IL-2, to Clare Rogers and David Brott for flow cytometric analyses, to Liberty Teodoro, Sheila Chang, and Ulrike Vanderwulbecke for technical assistance, and to Marcia Bauer and Kim Van Walbeck for preparation of the manuscript. We are grateful to the surgical, operating room, and rheumatology clinic staff of the University of Michigan Medical Center, as well as Dr. G. Weseloch and Dr. K. Gluckert in the Department of Orthopedic Surgery at the University of Erlangen-Nurnberg for the provision of synovial fluid and synovial tissue specimens.

This work was supported by National Institutes of Health grant AR38477, by grants from the Michigan Chapter of the Arthritis Foundation, by the Hulda Irene Duggan Arthritis Investigator Award of the Arthritis Foundation to David A. Fox, and by Deutsche Forschungsgemeinschaft grant Ki 329/2-1 to Raimund Kinne.

\section{References}

1. Ishikawa, H., and M. Ziff. 1976. Electron microscopic observations of immunoreactive cells in the rheumatoid synovial membrane. Arthritis Rheum. 19:1-14.

2. Trentham, D. E., R. A. Dynesius, and J. R. David. 1978. Passive transfer by cells of type II collagen-induced arthritis in rats. J. Clin. Invest. 62:359-366.

3. Holoshitz, J., Y. Naparstek, A. Ben-Nun, and I. R. Cohen. 1983. Lines of $\mathrm{T}$ lymphocytes induce or vaccinate against autoimmune arthritis. Science (Wash. DC). 219:56-58.

4. Holoshitz, J., A. Matitiau, and I. R. Cohen. 1984. Arthritis induced in rats by cloned $\mathrm{T}$ lymphocytes responsive to mycobacteria but not to collagen type II. J. Clin. Invest. 73:211-215.

5. Van Eden, W., J. Holoshitz, Z. Nevo, A. Frenkel, A. Klajman, and I. R. Cohen. 1985. Arthritis induced by a T-lymphocyte clone that responds to mycobacterium tuberculosis and to cartilage proteoglycans. Proc. Natl. Acad. Sci. USA. 82:5117-5120.

6. Cohen, I. R., J. Holoshitz, W. Van Eden, and A. Frenkel. 1985. T lymphocyte clones illuminate pathogenesis and affect therapy of experimental arthritis. Arthritis Rheum. 28:841-845.

7. Allen, J. B., D. G. Malone, S. M. Wahl, G. B. Calandra, and R. L. Wilder. 1985. Role of the thymus in streptococcal cell wall-induced arthritis and hepatic granuloma formation. Comparative studies of pathology and cell wall distribution in athymic and euthymic rats. $J$. Clin. Invest. 76:1042-1056. 
8. Hurd, E. R., and M. Ziff. 1974. Parameters of improvement in patients with rheumatoid arthritis treated with cyclophosphamide. $A r$ thritis Rheum. 17:72-78.

9. Clements, P. J., D. T. Y. Yu, J. Levy, H. E. Paulus, and E. V. Barnett. 1974. Effects of cyclophosphamide on B- and T-lymphocytes in rheumatoid arthritis. Arthritis Rheum. 17:347-353.

10. Yu, D. T., P. J. Clements, J. B. Peter, J. Levy, H. E. Paulus, E. V. Barnett. 1974. Lymphocyte characteristics in rheumatic patients and effect of azathioprine therapy. Arthritis Rheum. 17:37-45.

11. Paulus H. E., H. I. Machleder, S. Levine, D. T. Y. Yu, and N. S. McDonald. 1977. Lymphocyte involvement in rheumatoid arthritis. Studies during thoracic duct drainage. Arthritis Rheum. 20:12491262.

12. Lipsky, P. E., and M. Ziff. 1977. Inhibition of antigen- and mitogen-induced human lymphocyte proliferation by gold compounds. J. Clin. Invest. 59:455-466.

13. Machleder, H. I., and H. Paulus. 1978. Clinical and immunological alterations observed in patients undergoing long-term thoracic duct drainage. Surgery (St. Louis). 84:157-163.

14. Ueo, T., S. Tanaka, Y. Tominaga, H. Ogawa, and T. Sakurami. 1979. The effect of thoracic duct drainage on lymphocyte dynamics and clinical symptoms in patients with rheumatoid arthritis. Arthritis Rheum. 22:1405-1412.

15. Karsh, J., D. G. Wright, J. H. Klippel, J. L. Decker, A. B. Deisseroth, and M. W. Flye. 1979. Lymphocyte depletion by continuous flow cell centrifugation in rheumatoid arthritis. Clinical effects. Arthritis Rheum. 22:1055-1059.

16. Kotzin, B. L., S. Strober, E. G. Engleman, A. Calin, R. T. Hoppe, G. S. Kansas, C. P. Terrell, and H. S. Kaplan. 1981. Treatment of intractable rheumatoid arthritis with total lymphoid irradiation. $N$. Engl. J. Med. 305:969-976.

17. Trentham, D. E., J. A. Belli, R. J. Anderson, J. A. Buckley, E. J. Goetzl, J. R. David, and K. F. Austen. 1981. Clinical and immunologic effects of fractionated total lymphoid irradiation in refractory rheumatoid arthritis. N. Engl. J. Med. 305:976-982.

18. Kotzin, B. L., G. S. Kansas, E. G. Engleman, R. T. Hoppe, H. S. Kaplan, and S. Strober. 1983. Changes in T-cell subsets in patients with rheumatoid arthritis treated with total lymphoid irradiation. Clin. Immunol. Immunopathol. 27:250-260.

19. Lipsky, P. E. 1984. Immunosuppression by D-penicillamine in vitro. Inhibition of human $\mathrm{T}$ lymphocyte proliferation by copper- or ceruloplasmin-dependent generation of hydrogen peroxide and protection by monocytes. J. Clin. Invest. 73:53-65.

20. Yocum, D. E., J. H. Klippel, R. L. Wilder, N. L. Gerber, H. A. Austin, III, S. M. Wahl, L. Lesko, J. R. Minor, H. G. Preuss, C. Yarboro, C. Berkebile, and S. Dougherty. 1988. Cyclosporin A in severe, treatment-refractory rheumatoid arthritis. Ann. Intern. Med. 109:863.

21. Van Boxel, J. A., and S. A. Paget. 1975. Predominantly T-cell infiltrate in rheumatoid synovial membranes. N. Engl. J. Med. 293:517-520.

22. Bankhurst, A. D., G. Husby, and R. C. Williams. 1976. Predominance of $T$ cells in the lymphocytic infiltrates of synovial tissues in rheumatoid arthritis. Arthritis Rheum. 19:555-562.

23. Burmester, G. R., D. T. Y. Yu, A. M. Irani, and R. J. Winchester. 1981. Ia $+\mathrm{T}$ cells in synovial fluid and tissues of patients with rheumatoid arthritis. Arthritis Rheum. 24:1370-1376.

24. Fox, R. I., S. Fong, N. Sabharwal, S. A. Carstens, P. C. Kung, and J. H. Vaughan. 1982. Synovial fluid lymphocytes differ from peripheral blood lymphocytes in patients with rheumatoid arthritis. $J$. Immunol. 128:351-354.

25. Hemler, M. E., D. Glass, J. S. Coblyn, and J. G. Jacobson 1986. Very late activation antigens on rheumatoid synovial fluid $T$ lymphocytes. Association with stages of T cell activation. J. Clin. Invest. 78:696-702.

26. Stastny, P. 1978. Association of the B cell alloantigen DRw4 with rheumatoid arthritis. $N$. Engl. J. Med. 298:869-871.

27. Goronzy, J., C. M. Weyand, and C. G. Fathman. 1986. Shared
T cell recognition sites on human histocompatibility leukocyte antigen class II molecules of patients with seropositive rheumatoid arthritis. $J$. Clin. Invest. 77:1042-1049.

28. Singal, D. P., B. Reid, Y. B. Kassam, M. D'Souza, W. G. Bensen, and J. D. Adachi. 1987. HLA-DQ beta-chain polymorphism in HLA-DR4 haplotypes associated with rheumatoid arthritis. Lancet. ii: $1118-1120$.

29. Holmdahl, R., L. Klareskog, K. Rubin, E. Larsson, and H. Wigzell. 1985. T lymphocytes in collagen II-induced arthritis in mice. Characterization of arthritogenic collagen II-specific T-cell lines and clones. Scand. J. Immunol. 22:295-306.

30. Helfgott, S. M., R. Dynesius-Trentham, E. Brahn, and D. E. Trentham. 1985. An arthritogenic lymphokine in the rat. J. Exp. Med. 162:1531-1545.

31. Amento, E. P., J. T. Kurnick, A. Epstein, and S. M. Krane. 1982. Modulation of synovial cell products by a factor from a human cell line: T lymphocyte induction of a mononuclear cell factor. Proc. Natl. Acad. Sci. USA 79:5307-5311.

32. Brinckerhoff, C. E., and P. M. Guyre. 1985. Increased proliferation of human synovial fibroblasts treated with recombinant immune interferon. J. Immunol. 134:3142-3146.

33. Kammer, G. M., A. I. Sapolsky, and C. J. Malemud. 1985. Secretion of an articular cartilage proteoglycan-degrading enzyme activity by murine T lymphocytes in vitro. J. Clin. Invest. 76:395-402.

34. Brahn, E., and D. E. Trentham. 1984. Antigen-specific suppression of collagen arthritis by adoptive transfer of spleen cells. Clin. Immunol. Immunopathol. 31:124-131.

35. Van Eden, W., J. Holoshitz, and I. Cohen. 1987. Antigenic mimicry between mycobacteria and cartilage proteoglycans: the model of adjuvant arthritis. Concepts Immunopathol. 4:144-170.

36. Ranges, G. E., S. Sriram, and S. M. Cooper. 1985. Prevention of type II collagen-induced arthritis by in vivo treatment with antiL3T4. J. Exp. Med. 162:1105-1110.

37. Takagishi, K., N. Kaibara, T. Hotokebuchi, C. Arita, M. Morinaga, and K. Arai. 1986. Effects of cyclosporin on collagen-induced arthritis in mice. Ann. Rheum. Dis. 45:339-344.

38. Holoshitz, J., I. Drucker, A. Yaretzky, E. Van Eden, A. Klajman, Z. Lapidot, A. Frenkel, and I. R. Cohen. 1986. T lymphocytes of rheumatoid arthritis patients show augmented reactivity to a fraction of mycobacteria cross-reactive with cartilage. Lancet. ii:305-309.

39. Van Eden, W., J. E. R. Thole, R. van der Zee, A. Noordzij, J. D. A. van Embden, E. J. Hensen, and I. R. Cohen. 1988. Cloning of the mycobacterial epitope recognized by $T$ lymphocytes in adjuvant arthritis. Nature (Lond.). 331:171-173.

40. Res, P. C. M., F. C. Breedveld, J. D. A. Van Embden, C. G. Schaar, W. Van Eden, I. R. Cohen, and R. R. P. de Vries. 1988. Synovial fluid $\mathrm{T}$ cell reactivity against $65 \mathrm{kD}$ heat shock protein of mycobacteria in early chronic arthritis. Lancet. ii:478-480.

41. Jalkanen, S., A. C. Steere, R. I. Fox, and E. C. Butcher. 1986. A distinct endothelial cell recognition system that controls lymphocyte traffic into inflamed synovium. Science (Wash. DC). 233:556-558.

42. Higgs, J. B., W. Zeldes, K. Kozarsky, M. Schteingart, L. Kan, P. Bohlke, K. Krieger, W. Davis, and D. A. Fox. 1988. A novel pathway of human $\mathrm{T}$ lymphocyte activation. Identification by a monoclonal antibody generated against a rheumatoid synovial T cell line. J. Immunol. 140:3758-3765.

43. Knapp, W., editor. 1990. Leucocyte Typing IV. Oxford University Press, Oxford.

44. Arnett, F. C., S. M. Edworthy, D. A. Bloch, D. J. McShane, J. F. Fries, N. S. Cooper, L. A. Healey, S. R. Kaplan, M. H. Liang, H. S. Luthra, T. A. Medsger, Jr., D. M. Mitchell, D. H. Neustadt, R. S. Pinals, J. G. Schaller, J. T. Sharp, R. L. Wilder, and G. G. Hunder. 1988. The American Rheumatism Association 1987 revised criteria for the classification of rheumatoid arthritis. Arthritis Rheum. 31:315324.

45. Meuer, S. C., R. E. Hussey, M. Fabbi, D. A. Fox, O. Acuto, K. A. Fitzgerald, J. C. Hodgdon, J. P. Protentis, S. F. Schlossman, and E. L. Reinherz. 1984. An alternative pathway of T cell activation: a 
functional role for the $50 \mathrm{Kd} \mathrm{T} 11$ sheep erythrocyte binding protein. Cell. 36:897-906.

46. Reinherz, E. L., S. C. Meuer, K. A. Fitzgerald, R. E. Hussey, H. Levine, and S. F. Schlossman. 1982. Antigen recognition by human T lymphocytes is linked to surface expression of the T3 molecular complex. Cell. 30:735-743.

47. Meuer, S. C., S. F. Schlossman, and E. L. Reinherz. 1982. Clonal analysis of human cytotoxic lymphocytes: T4+ and T8+ effector $T$ cells recognize products of different major histocompatibility complex regions. Proc. Natl. Acad. Sci. USA 70:4395-4399.

48. Nadler, L. M., P. Stashenko, R. Hardy, J. M. Pesando, E. J. Yunis, and S. F. Schlossman. 1981. Monoclonal antibodies defining serologically distinct HLA-D/DR related Ia-like antigens in man. Hum. Immunol. 1:77-90.

49. Hercend, T., J. D. Griffin, A. Bensussan, R. E. Schmidt, M. A. Edson, A. Brennan, C. Murray, J. F. Daley, S. F. Schlossman, and J. Ritz. 1985. Generation of monoclonal antibodies to a human natural killer clone: characterization of two natural killer-associated antigens, NKH1 and NKH2, expressed on subsets of large granular lymphocytes. J. Clin. Invest. 75:932-943.

50. Todd, R. F., III, L. M. Nadler, and S. F. Schlossman. 1981. Antigens on human monocytes identified by monoclonal antibodies. J. Immunol. 126:1435-1442.

51. Stashenko, P., L. M. Nadler, R. Hardy, and S. F. Schlossman. 1980. Characterization of a human B lymphocyte-specific antigen. $J$. Immunol. 125:1678-1685.

52. Fox, D. A., R. E. Hussey, K. A. Fitzgerald, A. Bensussan, J. F. Daley, S. F. Schlossman, and E. L. Reinherz. 1985. Activation of human thymocytes via the $50 \mathrm{Kd} T 11$ sheep erythrocyte binding protein induces the expression of interleukin 2 receptors on both $\mathrm{T} 3+$ and T3- populations. J. Immunol. 133:330-335.

53. Fox, D. A., R. E. Hussey, K. A. Fitzgerald, O. Acuto, C. Poole, L. Palley, J. F. Daley, S. F. Schlossman, and E. L. Reinherz. 1984. Ta, a novel $105 \mathrm{KD}$ human $\mathrm{T}$ cell activation defined by a monoclonal antibody. J. Immunol. 133:1250-1256.

54. McMichael, A. J., and F. Gotch. 1987. T-Cell antigens: new and previously defined clusters. In Leucocyte Typing III. A. J. McMichael, editor. Oxford University Press, Oxford. p. 106.

55. Beverly, P. L. C., and R. E. Callard. 1981. Distinctive functional characteristics of human " $T$ " lymphocytes defined by $E$ rosetting or a monoclonal anti-T cell antibody. Eur. J. Immunol. 11:329334.

56. Smith, S. H., M. H. Brown, D. Rowe, R. E. Callard, and P. L. C. Beverly. 1986. Functional subsets of human helper-inducer cells defined by a new monoclonal antibody, UCHL1. Immunology. 58:6370.

57. Meuer, S. C., R. E. Hussey, D. A. Cantrell, J. C. Hodgdon, S. F. Schlossman, K. A. Smith, and E. L. Reinherz. 1984. Triggering of the T3-Ti antigen-receptor complex results in clonal T-cell proliferation through an interleukin 2-dependent autocrine pathway. Proc. Natl. Acad. Sci. USA. 81:1509-1513.

58. Hafler, D. A., D. A. Fox, D. Benjamin, and H. L. Weiner. 1986. Antigen reactive memory $\mathrm{T}$ cells are defined by $\mathrm{Ta}_{1} . J$. Immunol. 137:414-418.

59. Veys, E. M., P. Hermanns, G. Verbruggen, J. Schindler, and G. Goldstein. 1982. Evaluation of $T$ cell subsets with monoclonal antibodies in synovial fluid in rheumatoid arthritis. J. Rheumatol. 9:821826.

60. van de Putte, L. B. A., C. J. L. M. Meijer, G. J. M. Lafeber, R. Kleinjan, and A. Cats. 1976. Lymphocytes in rheumatoid and nonrheumatoid synovial fluids. Nonspecificity of high T-cell and low Bcell percentages. Ann. Rheum. Dis. 35:451-455.

61. Romain, P. L., G. R. Burmester, R. W. Enlow, and R. J. Winchester. 1982. Multiple abnormalities in immunoregulatory function of synovial compartment $T$ cells in patients with rheumatoid arthritis: recognition of a helper augmentation effect. Rheumatol. Int. 2:121-127.

62. Pitzalis, C., G. Kingsley, J. S. S. Lanchbury, J. Murphy, and
G. S. Panayi. 1987. Expression of HLA-DR, DQ and DP antigens and interleukin-2 receptor on synovial fluid $T$ lymphocyte subsets in rheumatoid arthritis: evidence for "frustrated" activation. J. Rheumatol. 14:662-666.

63. Cush, J. J., P. E. Lipsky. 1988. Phenotypic analysis of synovial tissue and peripheral blood lymphocytes isolated from patients with rheumatoid arthritis. Arthritis Rheum. 31:1230-1238.

64. Bergroth, V., Y. T. Konttinen, P. Pelkonen, M. Haapala, J. Haapasaari, D. Nordstrom, I. Kunnamo, and C. Friman. 1988. Synovial fluid lymphocytes in different subtypes of juvenile rheumatoid arthritis. Arthritis Rheum. 31:780-783.

65. Cantrell, D. A., and K. A. Smith. 1983. Transient expression of interleukin 2 receptors. Consequences for T cell growth. J. Exp. Med. 158:1895-1911.

66. Burmester, G. R., B. Jahn, M. Gramatzki, J. Zacher, and J. Kalden. 1984. Activated $\mathrm{T}$ cells in vivo and in vitro: divergence in expression of Tac and Ia antigens in the nonblastoid small $\mathrm{T}$ cells of inflammation and normal $\mathrm{T}$ cells activated in vitro. $J$. Immunol. 133:1230-1234

67. Waalen, K., O. Forre, and J. B. Natvig. 1988. Dendritic cells in rheumatoid inflammation. Springer Semin. Immunopathol. 10:141156.

68. Emery, P., K. C. Gentry, I. R. Mackay, K. D. Muirden, and M. Rowley. 1987. Deficiency of the suppressor inducer subset of $T$ lymphocytes in rheumatoid arthritis. Arthritis Rheum. 30:849-856.

69. Morimoto, C., P. L. Romain, D. A. Fox, P. Anderson, M. DiMaggio, H. Levine, and S. F. Schlossman. 1988. Abnormalities in CD4+ T-lymphocyte subsets in inflammatory rheumatic diseases. Am. J. Med. 84:817-825.

70. Baadsgaard, O., P. Tong, E. Hansen, L. Chan, A. Mannie, G. L. Wantzin, J. J. Voorhees, D. A. Fox, and K. D. Cooper. 1988. Lesional psoriasis T cell clones express UM4D4, the surface component of an antigen independent $\mathrm{T}$ cell activation pathway. Clin. Res. 36:631A.

71. Fox, D. A., L. K. Chan, L. Kan, O. Baadsgaard, and K. D. Cooper. 1989. Expression and function of the UM4D4 antigen in human thymus. J. Immunol. 143:2166-2175.

72. Clement, L. T., A. B. Tilden, and N. E. Dunlap. 1985. Analysis of the monocyte $\mathrm{Fc}$ receptors and antibody-mediated cellular interactions required for the induction of $\mathrm{T}$ cell proliferation by anti-T3 antibodies. J. Immunol. 135:165-171.

73. Hara, T., and S. M. Fu. 1985. Human $T$ cell activation. I. Monocyte-independent activation and proliferation induced by antiT3 monoclonal antibodies in the presence of tumor promoter 12-0tetradecanoyl phorbol-13 acetate. J. Exp. Med. 161:641-656.

74. Lance, E. M., and S. C. Knight. 1974. Immunologic reactivity in rheumatoid arthritis: response to mitogens. Arthritis Rheum. 17:513-520.

75. Hepburn, B., F. C. McDuffie, and R. E. Ritts, Jr. 1976. Impaired blastogenic response of lymphocytes from synovial fluid and peripheral blood of patients with rheumatoid arthritis. J. Rheumatol. 3:118-123.

76. Silverman, H. A., J. S. Johnson, J. H. Vaughan, and J. C. Mcglamory. 1976. Altered lymphocyte reactivity in rheumatoid arthritis. Arthritis Rheum. 19:509-515.

77. Andrianakos, A. A., J. T. Sharp, D. A. Person, M. D. Lidsky, and J. Duffy. 1977. Cell-mediated immunity in rheumatoid arthritis. Ann. Rheum. Dis. 36:13-20.

78. Menard, H. A., J. Dion, and C. Richard. 1977. Antinuclear antibody: predictive of lymphocyte response in rheumatoid arthritis. $J$. Rheumatol. 4:21-26.

79. Stratton, J. A., and J. B. Peter. 1978. The responses of peripheral blood and synovial fluid lymphocytes of patients with rheumatoid arthritis to in vitro stimulation with mitogens. Clin. Immunol. Immunopathol. 10:233-241.

80. Froebel, K., R. D. Sturrock, P. Reynolds, A. Grennan, R. Roxburgh, and R. N. M. MacSween. 1979. In-vitro reactions of lymphocytes in rheumatoid arthritis and other rheumatic diseases. Ann. Rheum. Dis. 38:535-543. 
81. Runge, L. A. 1981. In vitro lymphocyte response in early rheumatoid arthritis. J. Rheumatol. 8:468-475.

82. Slavin, S., and S. Strober. 1981. In-vitro T cell mediated function in patients with active rheumatoid arthritis. Ann. Rheum. Dis. 40:60-63.

83. Silver, R. M., D. Redelman, and N. J. Zvaifler. 1983. Studies of rheumatoid synovial fluid lymphocytes. II. A comparison of their behavior with blood mononuclear cells in the autologous mixed lymphocyte reaction and response to TCGF. Clin. Immunol. Immunopathol. 27:15-27.

84. Pope, R. M., L. McChesney, N. Talal, and M. Fischbach. 1984. Characterization of the defective autologous mixed lymphocyte response in rheumatoid arthritis. Arthritis Rheum. 27:1234-1244.

85. Malone, D. G., S. M. Wahl, M. Tsokos, H. Cattell, J. L. Decker, and R. L. Wilder. 1984. Immune function in severe, active rheumatoid arthritis. A relationship between peripheral blood mononuclear cell proliferation to soluble antigens and synovial tissue immunohistologic characteristics. J. Clin. Invest. 74:1173-1185.

86. Haraoui, B., R. L. Wilder, D. G. Malone, J. B. Allen, I. M. Katona, and S. M. Wahl. 1984. Immune function in severe, active rheumatoid arthritis: a relationship between peripheral blood mononuclear cell proliferation to soluble antigens and mononuclear cell subset profiles. J. Immunol. 133:697-701.

87. Lotz, M., C. D. Tsoukas, C. A. Robinson, C. A. Dinarello, D. A. Carson, and J. H. Vaughan. 1986. Basis for defective responses of rheumatoid arthritis synovial fluid lymphocytes to anti-CD3 (T3) antibodies. J. Clin. Invest. 78:713-721.
88. Kingsley, G. H., C. Pitzalis, and G. S. Panayi. 1987. Abnormal lymphocyte reactivity to self-major histocompatibility antigens in rheumatoid arthritis. J. Rheumatol. 14:667-673.

89. Emery, P., N. Wood, K. Gentry, A. Stockman, I. R. Mackay, and O. Bernard. 1988. High-affinity interleukin-2 receptors on blood lymphocytes are decreased during active rheumatoid arthritis. Arthritis Rheum. 31:1176-1181.

90. Miossec, P., A. Kashiwado, M. Ziff. 1987. Inhibitor of interleukin-2 in rheumatoid synovial fluid. Arthritis Rheum. 30:121-129.

91. Kashiwado, T., P. Miossec, N. Oppenheimer-Marks, and M. Ziff. 1987. Inhibitor of interleukin-2 synthesis and response in rheumatoid synovial fluid. Arthritis Rheum. 30:1339-1347.

92. Keystone, E. C., K. M. Snow, C. Bombardier, C.-H. Chang, D. L. Nelson, and L. A. Rubin. 1988. Elevated soluble interleukin-2 receptor levels in the sera and synovial fluids of patients with rheumatoid arthritis. Arthritis Rheum. 31:844-849.

93. Denning, S. M., M. L. Dustin, T. A. Springer, K. H. Singer, and B. F. Haynes. 1988. Purified LFA-3 antigen activates human thymocytes via the CD2 pathway. J. Immunol. 141:2980-2985.

94. Fox, D. A., S. F. Schlossman, E. L. Reinherz. 1986. Regulation of the alternative pathway of $\mathrm{T}$ cell activation by anti-T3 monoclonal antibody. J. Immunol. 136:1945-1950.

95. Yang, S. Y., S. Chouaib, and B. Dupont. 1986. A common pathway for T lymphocyte activation involving both the CD3-Ti complex and CD2 sheep erythrocyte receptor determinants. J. Immunol. 137:1097-1100. 